\title{
Field Assessment to Determine The KIBLAH Direction of Mosques in MAKKAH
}

\author{
A. M. Abdel-Wahab
}

\begin{abstract}
Every Muslim must pray to ALLAH five times every day and they must direct their faces toward the KABAH (KIBLAH direction) in each prayer. Muslims Scientifics and Astronomers since the eighth century (A.D) have been concerned with the determination of the KIBLAH direction. The KIBLAH direction at any point on the earth's surface; assuming the earth to be a perfect sphere; is given by the great circle passing through that point and holy city MAKKAH. Furthermore, the KIBLAH direction from the geographic north at this point is the angle between the tangent of the meridian passing through this point and the KABAH (Azimuth). In this context, the KIBLAH direction can be determined by using the spherical triangle between this point, KABAH, and North Pole. Moreover, in MAKKAH itself the KIBLAH direction is the direction of the line connect the point to $K A B A H$. The KIBLAH direction can be determined by many methods as mathematical (by determining the geographic coordinates by GPS, graphical, observe the sun when it's above or below the KABAH, etc. This direction refers to the true north direction which can be located by the magnetic compass when the magnetic declination is known at that point. This study investigates the accuracy of compass in determining the KIBLAH direction in MAKKAH. The methodology includes drawing the azimuth line map which is used in determining the KIBLAH direction at any point in MAKKAH. The KIBLAH direction in a few mosques in MAKKAH has been tested using the azimuth line map and compass during this study. The prismatic compass with a telescope can be used to determine the direction of the KIBLAH in $M A K K A H$ provided that it is not affected by local gravity and that the place of its use is far from the field of local gravity and succession. The KIBLAH direction can be obtained from the map at any location inside MAKKAH. One can be used this technique either to determine KIBLAH direction during the construction of a new mosque or to check the KIBLAH direction in an existing mosque. It should always check the value of the declination angle $(\delta)$, in the case used the compass for determining the $\mathrm{KABLAH}$ direction because it changes annually within 3 minutes per year. The compass should not be used if the angle of difference is not known and in this case Theodolite or any other device can be used for setting out the KIBLAH direction after knowing the true north direction.
\end{abstract}

Keywords : declination angle, Magnetic Azimuth, True Azimuth, GPS, latitude, longitude, spherical triangle

\section{INTRODUCTION}

Mentioned in the Quran Kareem in Sura Al-Baqarah verse 144 in what means guidance to the direction of the

Revised Manuscript Received on December 30, 2019.

* Correspondence Author

A. M. Abdel-Wahab*, Civil Engineering Department, National Research Centre, Egypt (NRC).

(c) The Authors. Published by Blue Eyes Intelligence Engineering and Sciences Publication (BEIESP). This is an open access article under the CC BY-NC-ND license (http://creativecommons.org/licenses/by-nc-nd/4.0/)
KABAH during the prayer of Muslims anywhere in the world[5]. Also, in verses after this verse mentioned (in Al-Baqarah verse 144) three times that he came down on the conditions, the first thing for those who are scenes of the Kaibab, the second for those who are in MAKKA region from and the third for those who are in the rest of the country. In the hadith was narrated by IBN GREG about tender from IBN ABBAS, may Allah be pleased with them that the Messenger of Allah, peace be upon him said: "The Kaibab is a direction to the people in the mosque and the mosque is a direction to the people of the MAKKAH and the MAKKAH is a direction to the people of the land in the East and west of any location." or as The prophet Mohamed said (Fig. 1 a ,b, and c ) [5].

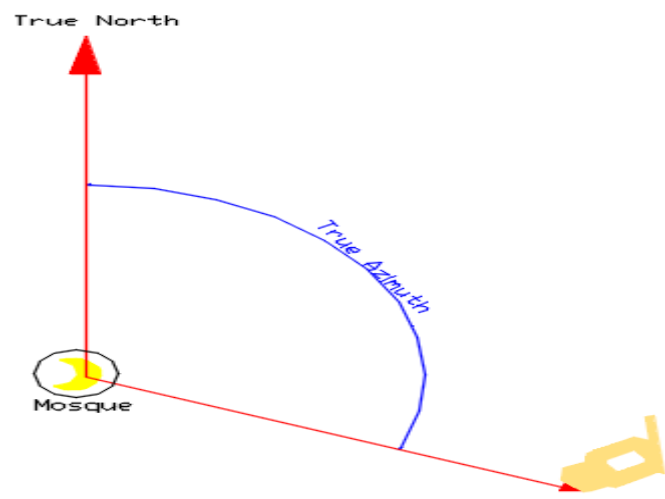

Fig. 1a The KIBLAH direction to the right side of the Grand Mosque

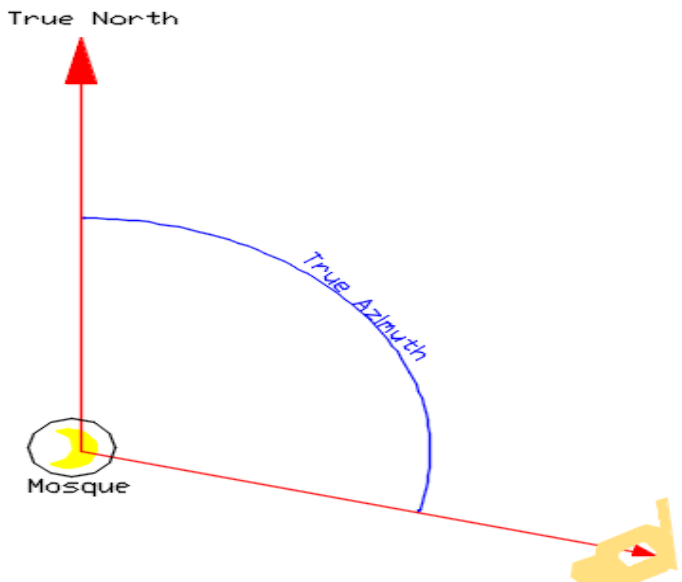

Fig. 1b The KIBLAH direction to the centre КАВАH 


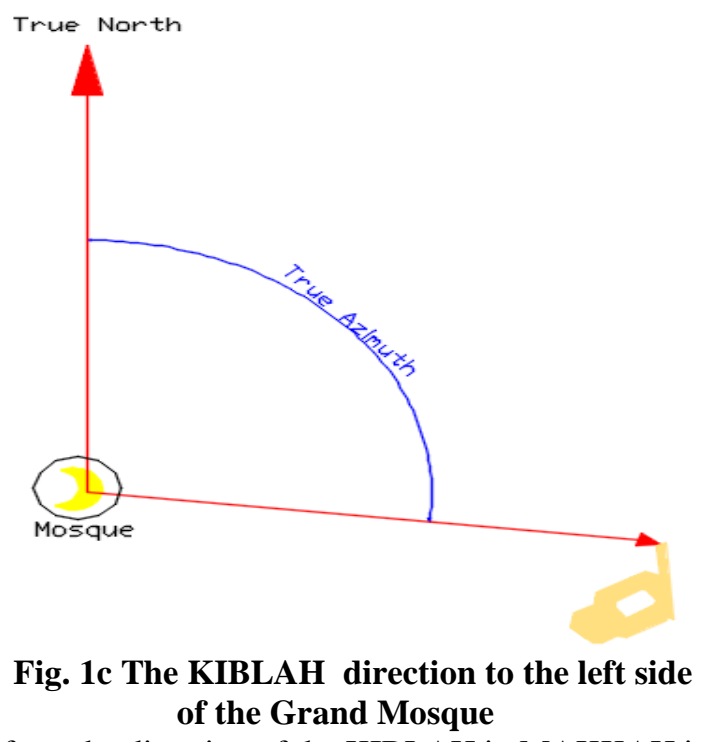

Therefore, the direction of the KIBLAH in MAKKAH is the direction of the KABAH and the mosque around it. This direction can be assigned arithmetically based on the north direction, which can be determined in several different ways, including the use of the magnetic compass after knowing the deflection angle. Special maps can be used for this purpose under special conditions. So, the current research is dealing with the accuracy of the prismatic compass in the appointment of the KIBLAH in the mosques of MAKKAH [8]. Also, this research included the establishment of a map of the direction of the KIBLAH in MAKKAH which can replace mathematical models [2], [3].

\section{KIBLAH DIRECTION CALCULATION}

The direction of the KIBLAH on anywhere on the Earth's surface is the direction between that place and the Grand Mosque, which is determined by a vertical plane that corresponds to the globe in an arc of a great circle. The angle of deviation of the KIBLAH direction from the north direction $(\alpha)$ can be calculated mathematically by solving the spherical triangle Fig. (2). By using the equation (1) [10]:

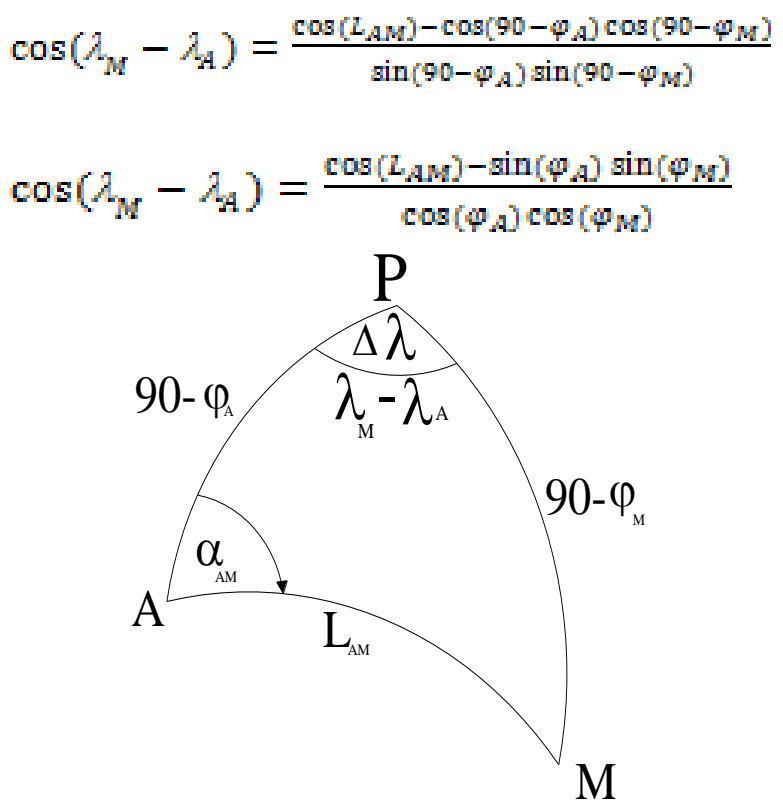

Fig.2 Spherical triangle [9].

Where: $\varphi_{A}$ and $\lambda_{A}$ (latitude and longitude) of the location of the mosque.
$\varphi_{M}$ and $\widehat{\lambda}_{M}$ (latitude and longitude) of the location of the KABAH.

This method is used to compute the deviation of 'KIBLAH direction from the real north direction in MAKKAH and other places which can be set out on field by different ways. In this research, the coordinates of mosques and $\operatorname{KABAH}(\varphi$, $\lambda$ ) were determined by GPS devices. On the other hand, these directions are rounded to the nearest half degree to compare with the directions which determined from the map, as shown in Table (1). Due to the difficulty of determining the direction of the real north, the direction of the KIBLAH can be assigned to the direction of the magnetic north.

The declination angle can be added to the magnetic north to get the true azimuth as shown in Fig (3) and Fig.(4).

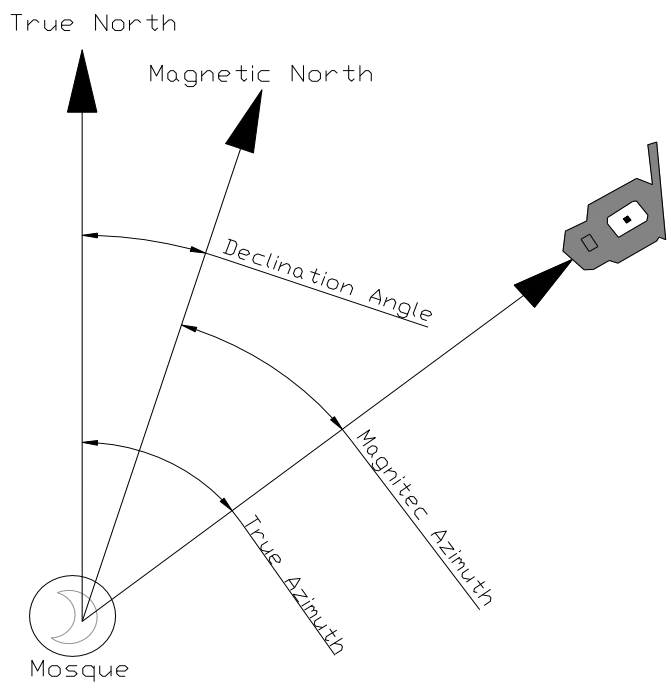

Fig. 3 The true and magnetic direction of the KIBLAH.

The magnetic compass would be used to set out the KIBLAH direction. The accuracy of magnetic compass depends on the following:-

a) The minimum reading of the compass, which depends on the diameter of the compass, which is usually half degree.

b) Local gravity as a result of the presence of metals, or electromagnetic field caused by high-voltage lines, ...... Etc.

The current research is concerned with determining the direction of the KIBLAH in MAKKAH, if one considers that the radius of the Holy Mosque is about 130 meters - up to 250 meters. On the other hand, the minimum reading of the compass is half degrees $\left(0.5^{\circ}\right)$. So, the maximum distance that a person is heading to the Grand Mosque (KABAH and the Grand Mosque around it) is $14 \mathrm{~km}$ from the KABAH. Also, if the diameter of the MAKKAH city will be considered about $25 \mathrm{~km}$, it can be said that the compass can be used to sign the direction of the KIBLAH in MAKKAH provided that it is far from Local gravity effect [4]. 


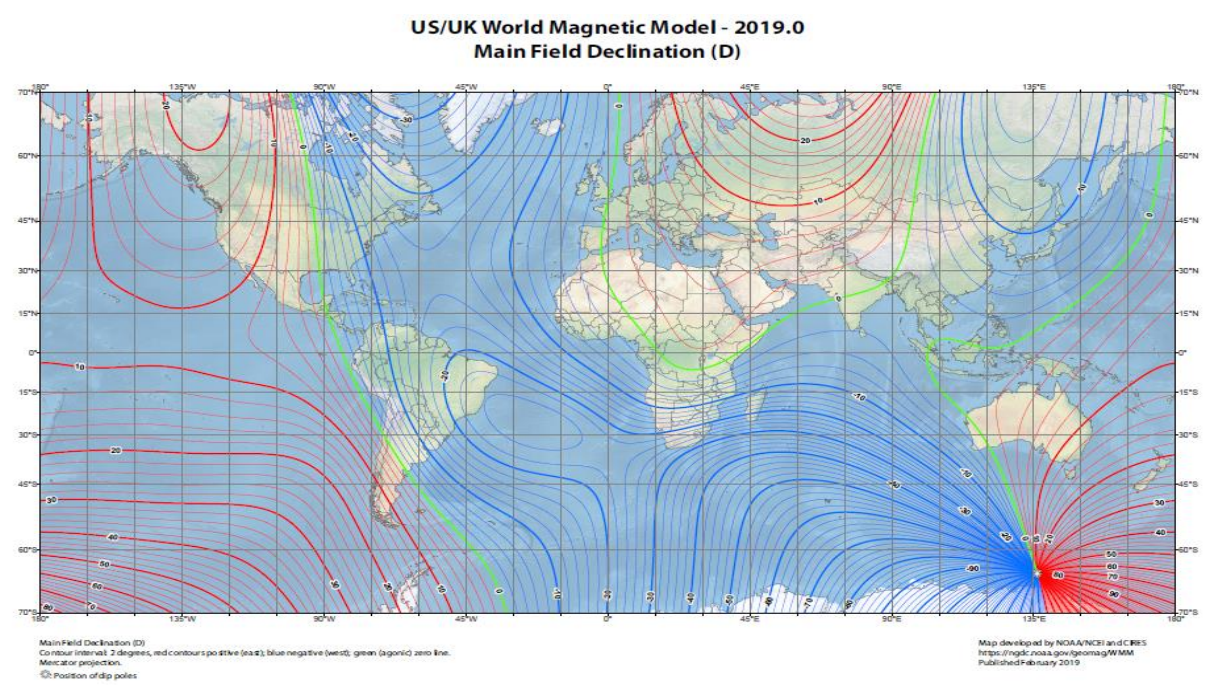

Fig.(4) The map of declination angles for the world[1].

\section{USING THE MAPS TO SET KIBLAH DIRECTION}

The map can be defined as representing the earth's surface (curve, surface) by defining the latitude \& longitude of all points and converted to plane coordinates (E, N), on the map as a plane surface. This process is known by map projection. The map projection process may cause some distortions. All projections have some distortions, such as:- Shape - Area Distance - Direction - Angle. The projection process maintains some earth of properties such as: -

- Equal Area projection is preserved the area (correct earth surface area).

- Conical projection (Lambert Conformal Conic) is preserved the shape (the angles are correctly).

- Azimuthal (Lambert Azimuthal) is preserved the directions (all directions are shown correctly).

- Distance is preserved the lines.

The current research will concentrate on the type of projection whose is preserving the direction.

Moreover, this means that the directions from one point to another on the map create an azimuth from the North equal to its corresponding on the earth's surface. So, according to the comments mentioned before, the required map should have the following?

1) The value of any direction on the map is valid direction. That means the direction from anywhere to MAKKAH on the map must be equal to its corresponding on the earth's surface.

2) This line (direction) from the place of (mosque) and the MAKKAH is the shortest path and this is achieved only if this line is an arc of a great circle.

Therefore, from the practical point of view, all the projection's types can't give the accurate direction from any point on the earth's surface (mosque) to another point (MAKKAH), especially with increasing the distance between the two points. So, the used maps to determine the direction don't prefer to be used in determining the direction of the KABLAH for location outside MAKKAH because the error increases as the distance from MAKKAH increases.

\section{MAP'S DIRECTION OF KIBLAH FOR THE MAKKAH}

Accordingly, to directional maps like Mercator's maps do not give the correct KIBLAH direction only in the vicinity of MAKKAH. Therefore, these maps give the correct KIBLAH direction in MAKKAH itself. Due to MAKKAH has a small area of (area about $491 \mathrm{~km}^{2}$ and diameter about $25 \mathrm{~km}$ ). So, corrections can be considered zero).

a) Methodology of producing map's direction and deduce the direction of the KIBLAH.

1)Obtained a recent, map of the city of MAKKAH was containing the majority of its features.

2)The KABAH was considered the center of the map Fig (5).

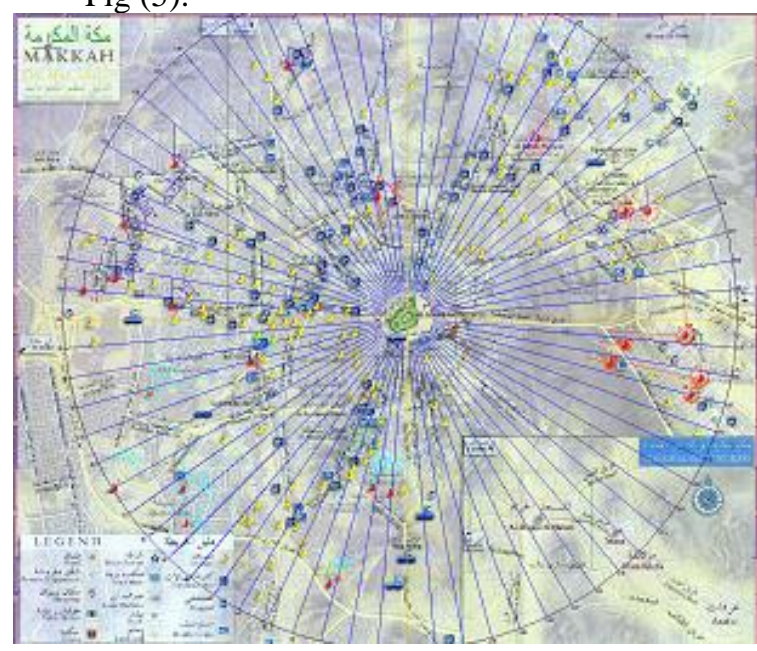

Fig. (5): Map of MAKKAH showing the deviation lines and the mosques which are tested

3) A 72 rays have been designed from the center of the KABAH every 5 degrees. Since these lines are drawn from the centered of the $\mathrm{KABAH}$, the deviation of these rays (from $0^{\circ}$ to $355^{\circ}$ ) represents the deviation of the KIBLAH in any 
4) places where these rays pass through it. Therefore, it can be deduced the KIBLAH deviation for any mosque located in any area between two rays of this place to the nearest half degree, as it is illustrated in Fig (6).

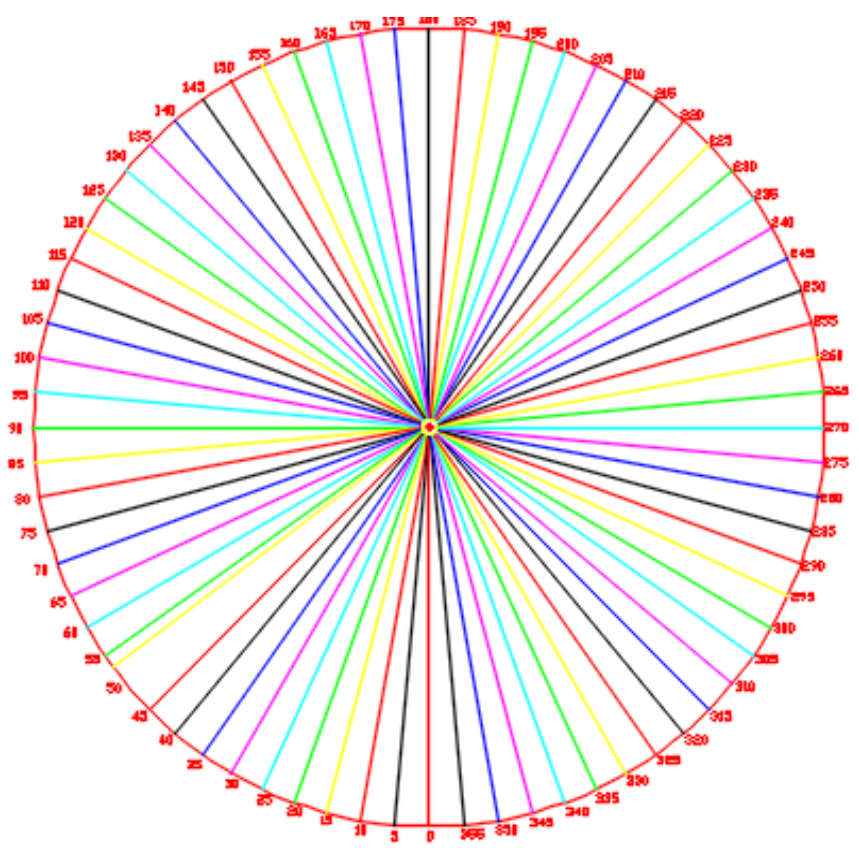

5) To test and evaluate the map in determining the direction of the KIBLAH, 21 mosques were selected with good distributions in different districts of Mecca and in different directions. For each mosque, processing steps algorithm were made, as appeared in the next section.

\section{RESULTS, AND ANALYSIS}

1) Measuring the direction of the line between the mosque and the KABAH $\left(\alpha_{\mathrm{T}}\right)$ through the direction of the lines of the KIBLAH and it represents the direction of the KIBLAH of this mosque - as shown in Table (I).

Fig. (6): The 72 Rays from KABAH every $5^{\circ}$

coverage the MAKKAH city.

Table - I: KIBLAH Direction from the Map and Mathematically

\begin{tabular}{|c|c|c|c|c|c|}
\hline$\#$ & Mosque Name & $\begin{array}{c}\text { Area Name } \\
\text { Inside MAKKAH }\end{array}$ & $\begin{array}{l}\text { KIBLAH Direction } \\
\text { from map }\end{array}$ & $\begin{array}{l}\text { KIBLAH Direction } \\
\text { Mathematical model }\end{array}$ & $\begin{array}{l}\text { KIBLAH Direction from } \\
\text { Mathematical model } \\
\text { For approximately to } 0.5^{\circ}\end{array}$ \\
\hline 1 & $\begin{array}{c}\text { AL- KHAIR } \\
\text { (الخير) }\end{array}$ & $\begin{array}{c}\text { ALRASIFA } \\
\text { (الرصيفة) }\end{array}$ & $060^{\circ} 00^{\prime} \quad 00 "$ & $060^{\circ} 02^{\prime} 00^{\prime \prime}$ & $060^{\circ} 00^{\prime}$ \\
\hline 2 & $\begin{array}{c}\text { PRINCESS SHEIKHA } \\
\text { (الأميرة شيخه) }\end{array}$ & $\begin{array}{c}\text { ALKHALIDIA } \\
\text { (الخالاية) }\end{array}$ & 053 ${ }^{\circ} 00^{\prime} 00^{\prime \prime}$ & $052^{\circ} 53^{\prime} 00^{\prime \prime}$ & $053^{\circ} 00^{\prime}$ \\
\hline 3 & $\begin{array}{l}\text { OTHMAN } \\
\text { BIN-AFFAN } \\
\text { (عثمان بن عفان) } \\
\end{array}$ & $\begin{array}{l}\text { ALMASFALA } \\
\text { (المسفلة) }\end{array}$ & $0^{\circ} 30^{\prime}$ 00" & $011^{\circ} 33^{\prime} 10^{\prime \prime}$ & $011^{\circ} 30^{\prime}$ \\
\hline 4 & $\begin{array}{c}\text { IMAM BUKHARI } \\
\text { (الإمام البخاري) }\end{array}$ & $\begin{array}{c}\text { ALMASFALA } \\
\text { (المسفلة) }\end{array}$ & 005 $05^{\circ}$ 00" & $004^{\circ} 53^{\prime} 19^{\prime \prime}$ & $005^{\circ} 00^{\prime}$ \\
\hline 5 & $\begin{array}{c}\text { ABU BAKR ALSADIQ } \\
\text { (أبو بكر الصديق) }\end{array}$ & $\begin{array}{c}\text { ALEAZIZI } \\
\text { (العزيزية) }\end{array}$ & $273^{\circ} 30^{\prime} 00^{\prime \prime}$ & $273^{\circ} 27^{\prime} 30^{\prime \prime}$ & $273^{\circ} 30^{\prime}$ \\
\hline 6 & (الإجابةAL'IIJABA ) & $\begin{array}{c}\text { ALMUEABADA } \\
\text { (المعابدة) }\end{array}$ & $216^{\circ} 00^{\prime} 00^{\prime \prime}$ & $216^{\circ} 13^{\prime} 50^{\prime \prime}$ & $216^{\circ} 00^{\prime}$ \\
\hline 7 & $\begin{array}{c}\text { MUHAMAD KURDY } \\
\text { (محمد كردي) }\end{array}$ & $\begin{array}{c}\text { ALSITIYN St. } \\
\text { (ش الستين) }\end{array}$ & $108^{\circ} 30^{\prime} 00^{\prime \prime}$ & $108^{\circ} 27^{\prime} 00^{\prime \prime}$ & $108^{\circ} 30^{\prime}$ \\
\hline 8 & (الزيتونة)ALZAYTUNA ) & $\begin{array}{c}\text { UMM AL QURA St. } \\
\text { (ش أم القرى) }\end{array}$ & $093^{\circ} 00^{\prime} 00^{\prime \prime}$ & $093^{\circ} 06^{\prime} 50^{\prime \prime}$ & $093^{\circ} 00^{\prime}$ \\
\hline 9 & $\begin{array}{c}\text { HAMZAT BIN EABD } \\
\text { ALMATLAB } \\
\text { (حزة بن عبد المطلب) }\end{array}$ & $\begin{array}{c}\text { ALEAZIZI } \\
\text { (العزيزية) }\end{array}$ & $281^{\circ} 30^{\prime} 00^{\prime \prime}$ & $281^{\circ} 28^{\prime} 20^{\prime \prime}$ & $281^{\circ} 30^{\prime}$ \\
\hline 10 & $\begin{array}{l}\text { FAQIH } \\
\text { (فقيه }\end{array}$ & $\begin{array}{c}\text { ALEAZIZI } \\
\text { (العزيزية) } \\
\end{array}$ & $285^{\circ} 00^{\prime} 00^{\prime \prime}$ & $285^{\circ} 00^{\prime} 15^{\prime \prime}$ & $285^{\circ} 00^{\prime}$ \\
\hline 11 & $\begin{array}{c}\text { PRINCE AHMED } \\
\text { (الأمير أحمد) }\end{array}$ & $\begin{array}{c}\text { ALRASIFA } \\
\text { (الرصيفة) }\end{array}$ & 074 $04^{\circ}$ '00" & $073^{\circ} 49^{\prime} 30^{\prime \prime}$ & $074^{\circ} 00^{\prime}$ \\
\hline 12 & $\begin{array}{c}\text { ALSABAK } \\
\text { (السباك) }\end{array}$ & $\begin{array}{c}\text { ALSHISHA St. } \\
\text { (الششة) }\end{array}$ & $244^{\circ} 00^{\prime} 00^{\prime \prime}$ & $243^{\circ} 59^{\prime} 50^{\prime \prime}$ & $244^{\circ} 00^{\prime}$ \\
\hline 13 & $\begin{array}{c}\text { TURKISTANI } \\
\text { (التركستاني) }\end{array}$ & $\begin{array}{l}\text { ALSITIYN St. } \\
\text { (ش الستنين) }\end{array}$ & 095 $05^{\circ}$ ' $00^{\prime \prime}$ & 095 $05^{\circ}$ ' $00^{\prime \prime}$ & $095^{\circ} 00^{\prime}$ \\
\hline 14 & $\begin{array}{l}\text { HAMAD AL THANI } \\
\text { (حمد آل ثاني) }\end{array}$ & $\begin{array}{l}\text { ALHAJI St. } \\
\text { (ش الحج) }\end{array}$ & $155^{\circ} 00^{\prime} 00^{\prime \prime}$ & $154^{\circ} 59^{\prime} 20^{\prime \prime}$ & $155^{\circ} 00^{\prime}$ \\
\hline
\end{tabular}




\begin{tabular}{|c|c|c|c|c|c|}
\hline 15 & $\begin{array}{c}\text { BAGHDADI } \\
\text { (البغدادي) } \\
\end{array}$ & $\begin{array}{c}\text { ALHUNDAWIA } \\
\text { (الهندوية) }\end{array}$ & 074 00' 00" & 074 ${ }^{\circ} 1^{\prime}$ '00" & 074 $^{\circ}$ 00' \\
\hline 16 & $\begin{array}{c}\text { BIN TURKI } \\
\text { (بن تركي) }\end{array}$ & $\begin{array}{c}\text { ALSHISHA } \\
\text { (الثششة) }\end{array}$ & $246^{\circ} 00^{\prime} 00 "$ & $246^{\circ} 16^{\prime} 15^{\prime \prime}$ & $246^{\circ} 00^{\prime}$ \\
\hline 17 & $\begin{array}{l}\text { ALHUDAA } \\
\text { (الهلىى) }\end{array}$ & $\begin{array}{c}\text { ALRASIFA } \\
\text { (الرصيفة) }\end{array}$ & $047^{\circ} 00 ' 00 "$ & $047^{\circ} 16^{\prime} 40^{\prime \prime}$ & $047^{\circ} 00^{\prime}$ \\
\hline 18 & $\begin{array}{c}\text { ALMUHAISNI } \\
\text { (المحيسني) }\end{array}$ & $\begin{array}{l}\text { ALEAZIZI } \\
\text { (العزيزية) }\end{array}$ & $276^{\circ} 30^{\prime} 00 "$ & $276^{\circ} 42^{\prime} 30^{\prime \prime}$ & $276^{\circ} 30^{\prime}$ \\
\hline 19 & $\begin{array}{l}\text { SULAIMAN } \\
\text { ALOBAID } \\
\text { (سليمان العبيا) }\end{array}$ & $\begin{array}{l}\text { ALEAZIZI } \\
\text { (العزيزية) }\end{array}$ & $282^{\circ} 00^{\prime} 00 "$ & $282^{\circ} 12^{\prime} 25^{\prime \prime}$ & $282^{\circ} 00^{\prime}$ \\
\hline 20 & $\begin{array}{l}\text { MUHAMAD ALSABIL } \\
\text { (محمد السبيل) }\end{array}$ & $\begin{array}{c}\text { KUDI } \\
\text { (كدي) }\end{array}$ & $016^{\circ} 30^{\prime} 00 "$ & $016^{\circ} 25^{\prime} \quad 20 "$ & $016^{\circ} 30^{\prime}$ \\
\hline 21 & $\begin{array}{l}\text { MASJID } 35 \\
\text { (مسجد 35) }\end{array}$ & $\begin{array}{c}\text { ALSITIYN St. } \\
\text { (ش الستين) }\end{array}$ & $0^{098^{\circ}} 00^{\prime}$ 00" & $097^{\circ} 46^{\prime} 45^{\prime \prime}$ & $098^{\circ} 00^{\prime}$ \\
\hline
\end{tabular}

2) KIBLAH direction will be calculated $\left(\alpha_{\mathrm{TC}}\right)$ for each of the mosques selected in the current research by measuring the coordinates by (GPS) - as shown in Table (I).

3) Comparing the values of KIBLAH direction from the true north, which are measured from the map with the values of KIBLAH direction which are calculated from the coordinates of each mosque. These values were found to be equal if the seconds and minutes were rounded to one degree and half degrees.

4) The direction of KIBLAH for any mosque will be found by measuring the direction of each line between the mosque and the left and right MASJID
AL-HARAM Mosque respectively $\alpha_{\mathrm{TR}} \& \alpha_{\mathrm{TL}}$. These values represent the range of KIBLAH direction from the true north direction in each of these mosques and these values- as shown in Table (II)[7].

5) To obtain the Magnetic declination angle ( $\delta$ ) for the MAKKAH city in the month of $1 / 2019$ through the site www.noaa.com is found $=3^{*} 28{ }^{\prime} \pm 17^{\prime} \mathrm{E}$ as shown in Figure 7. Also, the declination angle can be obtained by using the map of (US/UK World Magnetic Model - 2019 Main Field Declination (D)), as shown in figure (4) [6].

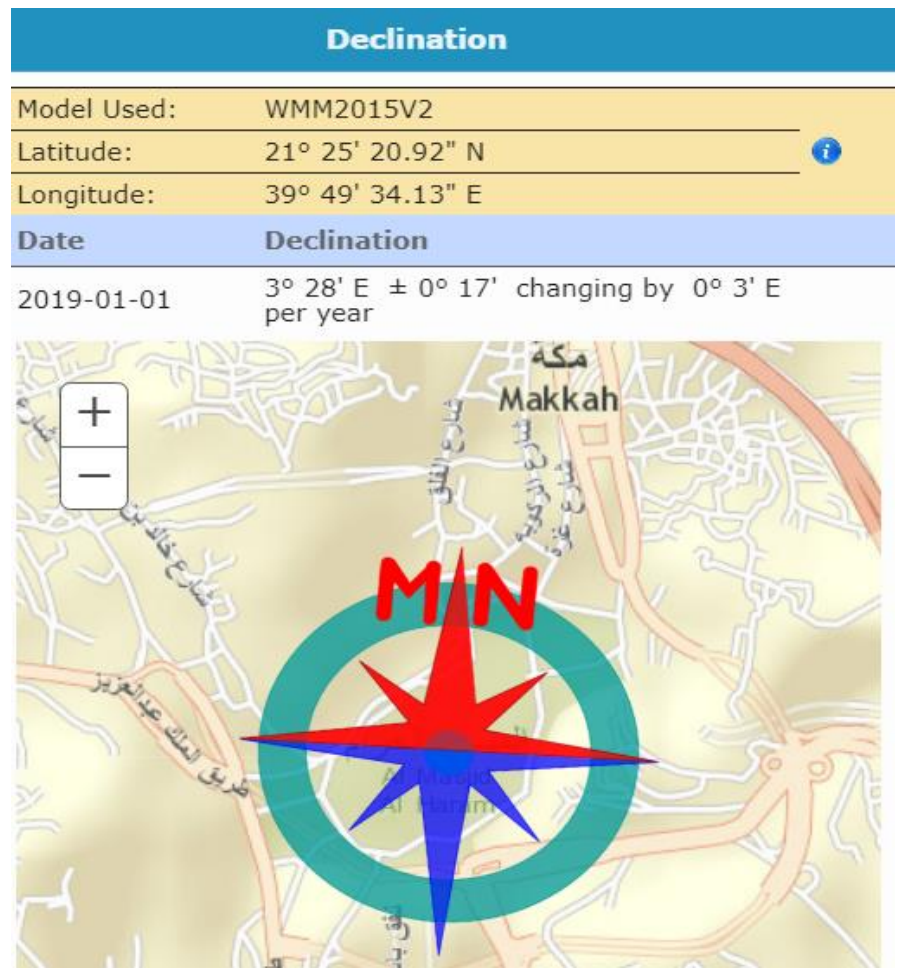

Fig.(7): Calculate the declination angle $\delta$ for MAKKAH

6) The direction of the KIBLAH was measured for the 21 mosques in the field, by using a prismatic compass with a telescope mounted on a tripod. Minimum reading of the compass is one degree and can be estimated to read up to 30 minutes. The measured values represent the magnetic Azimuth of the KIBLAH direction.

7) Adding the declination angle $(\delta)$ to the magnetic direction of the KIBLAH was measured from the field $(\mathrm{M} \alpha)$ to get the true direction (True Azimuth) of

the KIBLAH in these mosques according to equation (2).

Where:-

$$
\delta=\alpha_{T}-\alpha_{M}
$$

$\alpha_{\mathrm{T}}=$ True azimuth,

$\alpha_{\mathrm{M}}=$ Magnetic azimuth, and

$\delta=$ declination angle. 
8) Comparing the values of the real directions from to geographic coordinates of the KIBLAH with respect to the values of the range of left side and right side of the grand mosque. From the above results which are shown in table (2), most of mosques have direction of the KIBLAH in the range of correct directions of ALBEIT AL-HARAM(Grand Mosque). Some of them have a direction far from the center of the $\mathrm{KABAH}$ but they go to the grand mosque around the KABAH

\section{CONCLUSION}

From the above, the following conclusions can be concluded:

1) The prismatic compass with a telescope can be used to determine the direction of the KIBLAH in MAKKAH provided that, it is not affected by local gravity and that the place of its use is far from the field of local gravity and succession.

2) The KIBLAH direction can be obtained from the map at any location inside MAKKAH. One can be used this technique either to determine KIBLAH direction during the construction of a new mosque or to check the KIBLAH direction in an existing mosque.

3) It should always check the value of the declination angle $(\delta)$, in case of using the compass for determining the KIBLAH direction because it changes annually within 3 minutes per year.

4) The compass should not be used, if the angle of difference is not known. In this case, Theodolite or any other device can be used for setting out the KIBLAH direction after knowing the true north direction.

Table -II: Range Of The KIBLAH Direction For Some Mosques In MAKKAH To Left And Right Side Of the Grand Mosque.

\begin{tabular}{|c|c|c|c|c|c|c|c|}
\hline \multirow[b]{2}{*}{$\#$} & \multirow[b]{2}{*}{ Mosque Name } & \multirow[b]{2}{*}{$\begin{array}{c}\text { Area Name } \\
\text { Inside MAKKAH }\end{array}$} & \multicolumn{2}{|c|}{ KIBLAH Direction from map } & \multicolumn{2}{|c|}{$\begin{array}{c}\text { KIBLAH Direction from } \\
\text { field by Compass }\end{array}$} & \multirow{2}{*}{$\begin{array}{c}\text { Differenc } \\
\text { e between } \\
\text { direction } \\
\text { from map } \\
\text { and (field } \\
+\delta \text { ) }\end{array}$} \\
\hline & & & $\begin{array}{c}\text { To the } \\
\text { Centre of } \\
\text { KAABA( } \\
\alpha)\end{array}$ & $\begin{array}{c}\text { The range from left } \\
\text { side to right side of the } \\
\text { Grand Mosque( } \alpha_{T R} \& \\
\alpha T L)\end{array}$ & $\boldsymbol{\alpha}_{M}$ & $\begin{array}{c}\alpha_{M} \\
+ \\
\delta=\left(\begin{array}{ll}3^{\circ} & 28\end{array}\right)\end{array}$ & \\
\hline 1 & $\begin{array}{c}\text { AL- KHAIR } \\
\text { (الخير) }\end{array}$ & $\begin{array}{c}\text { ALRASIFA } \\
\text { (الرصيفة) }\end{array}$ & $060^{\circ} 00^{\prime}$ & $58^{\circ} 30^{\prime}-61^{\circ} 30^{\prime}$ & $057^{\circ} 00^{\prime}$ & $60^{\circ} 28^{\prime}$ & $-0^{\circ} 28$ \\
\hline 2 & $\begin{array}{l}\text { PRINCESS } \\
\text { SHEIKHA } \\
\text { (الاميرة شيخه) }\end{array}$ & $\begin{array}{l}\text { ALKHALIDIA } \\
\text { (الخاللية) }\end{array}$ & $053^{\circ} 00^{\prime}$ & $51^{\circ} 00^{\prime}-55^{\circ} 00^{\prime}$ & 051 ${ }^{\circ} 00^{\prime}$ & $54^{\circ} \quad 28^{\prime}$ & $-1^{\circ} 28^{\prime}$ \\
\hline 3 & $\begin{array}{l}\text { OTHMAN } \\
\text { BIN-AFFAN } \\
\text { (عثمان بن عفان) }\end{array}$ & $\begin{array}{c}\text { ALMASFALA } \\
\text { (المسفلة) }\end{array}$ & $011^{\circ} 30^{\prime}$ & $07^{\circ} 00^{\prime}-14^{\circ} 30^{\prime}$ & $010^{\circ} 00^{\prime}$ & $13^{\circ} 28^{\prime}$ & $-1^{\circ} 58^{\prime}$ \\
\hline 4 & $\begin{array}{c}\text { IMAM BUKHARI } \\
\text { (الإمام البخاري) }\end{array}$ & $\begin{array}{c}\text { ALMASFALA } \\
\text { (المسفلة) }\end{array}$ & $05^{\circ} 00^{\prime}$ & $00^{\circ} 30^{\prime}-0^{\circ} 00^{\prime}$ & $03^{\circ} 00^{\prime}$ & $06^{\circ} 28^{\prime}$ & $-1^{\circ} 28^{\prime}$ \\
\hline 5 & $\begin{array}{l}\text { ABU BAKR } \\
\text { ALSADIQ } \\
\text { (أبو بكر الصديق) }\end{array}$ & $\begin{array}{c}\text { ALEAZIZI } \\
\text { (العزيزية) }\end{array}$ & $273^{\circ} 30^{\prime}$ & $270^{\circ} 00^{\prime}-276^{\circ} 00^{\prime}$ & $270^{\circ} 00^{\prime}$ & $273^{\circ} 28^{\prime}$ & $-0^{\circ} 02^{\prime}$ \\
\hline 6 & (الإجابةAL'IIJABA ) & $\begin{array}{c}\text { ALMUEABADA } \\
\text { (المعابدة) }\end{array}$ & $216^{\circ} 00^{\prime}$ & $213^{\circ} 30^{\prime}-218^{\circ} 30^{\prime}$ & $212^{\circ} 00^{\prime}$ & $215^{\circ} 28^{\prime}$ & $0^{\circ} 32^{\prime}$ \\
\hline 7 & $\begin{array}{l}\text { MUHAMAD } \\
\text { KURDY } \\
\text { (محمد كردي) } \\
\end{array}$ & $\begin{array}{c}\text { ALSITIYN St. } \\
\text { (ش الستين) }\end{array}$ & $108^{\circ} 30^{\prime}$ & $106^{\circ} 30^{\prime}-112^{\circ} 00^{\prime}$ & $104^{\circ} 30^{\prime}$ & $107^{\circ} 28^{\prime}$ & $1^{\circ} 02^{\prime}$ \\
\hline 8 & $\begin{array}{c}\text { ALZAYTUNA } \\
\text { (الزيتونة) }\end{array}$ & $\begin{array}{c}\text { UMM AL QURA St. } \\
\text { (ش أم القرى) }\end{array}$ & $093^{\circ} 00^{\prime}$ & $90^{\circ} 30^{\prime}-97^{\circ} 00^{\prime}$ & $091^{\circ} 00^{\prime}$ & $94^{\circ} 28^{\prime}$ & $-1^{\circ} 28^{\prime}$ \\
\hline 9 & $\begin{array}{c}\text { HAMZAT BIN } \\
\text { EABD ALMATLAB } \\
\text { (حزة بن عبد المطب) } \\
\end{array}$ & $\begin{array}{c}\text { ALEAZIZI } \\
\text { (العزيزية) }\end{array}$ & $281^{\circ} 30^{\prime}$ & $278^{\circ} 00^{\prime}-283^{\circ} 30^{\prime}$ & $277^{\circ} 30^{\prime}$ & $280^{\circ} 28^{\prime}$ & $1^{\circ} 02^{\prime}$ \\
\hline 10 & $\begin{array}{c}\text { FAQIH } \\
\text { (فقيه) }\end{array}$ & $\begin{array}{c}\text { ALEAZIZI } \\
\text { (العزيزية) }\end{array}$ & $285^{\circ} 00^{\prime}$ & $281^{\circ} 00^{\prime}-287^{\circ} 00^{\prime}$ & $281^{\circ} 00^{\prime}$ & $284^{\circ} 28^{\prime}$ & $0^{\circ} 32^{\prime}$ \\
\hline 11 & $\begin{array}{c}\text { PRINCE AHMED } \\
\text { (الأمير أحمد) }\end{array}$ & $\begin{array}{c}\text { ALRASIFA } \\
\text { (الرصيفة) }\end{array}$ & $074^{\circ} 00^{\prime}$ & $72^{\circ} 00^{\prime}-76^{\circ} 00^{\prime}$ & 072 ${ }^{\circ} 00^{\prime}$ & $75^{\circ} 28^{\prime}$ & $-1^{\circ} 28^{\prime}$ \\
\hline 12 & $\begin{array}{c}\text { ALSABAK } \\
\text { (السباك) }\end{array}$ & $\begin{array}{c}\text { ALSHISHA St. } \\
\text { (الثشة) }\end{array}$ & $244^{\circ} 00^{\prime}$ & $241^{\circ} 30^{\prime}-246^{\circ} 30^{\prime}$ & $242^{\circ} 00^{\prime}$ & $245^{\circ} 28^{\prime}$ & $-1^{\circ} 28^{\prime}$ \\
\hline 13 & $\begin{array}{c}\text { TURKISTANI } \\
\text { (التركستاني) }\end{array}$ & $\begin{array}{c}\text { ALSITIYN St. } \\
\text { (ش الستين) }\end{array}$ & $095^{\circ} 00^{\prime}$ & $93^{\circ} 00^{\prime}-98^{\circ} 00^{\prime}$ & $091^{\circ} 00^{\prime}$ & $94^{\circ} 28^{\prime}$ & $0^{\circ} 32^{\prime}$ \\
\hline 14 & $\begin{array}{c}\text { HAMAD AL THANI } \\
\text { (حمد آل ثاني) }\end{array}$ & $\begin{array}{l}\text { ALHAJI St. } \\
\text { (ش الحج) }\end{array}$ & $155^{\circ} 00^{\prime}$ & $153^{\circ} 00^{\prime}-158^{\circ} 00^{\prime}$ & $151^{\circ} 00^{\prime}$ & $154^{\circ} 28^{\prime}$ & $0^{\circ} 32^{\prime}$ \\
\hline 15 & $\begin{array}{c}\text { BAGHDADI } \\
\text { (البغدادي) }\end{array}$ & $\begin{array}{c}\text { ALHUNDAWIA } \\
\text { (الهندوية) }\end{array}$ & $\mathbf{0 7 4}^{\circ}$ 00' & $71^{\circ} 00^{\prime}-77^{\circ} 00^{\prime}$ & $069^{\circ} 00^{\prime}$ & $72^{\circ} 28^{\prime}$ & $1^{\circ} 32^{\prime}$ \\
\hline 16 & $\begin{array}{l}\text { BIN TURKI } \\
\text { (بن تركي) }\end{array}$ & $\begin{array}{c}\text { ALSHISHA } \\
\text { (الشششة) }\end{array}$ & $246^{\circ} 00^{\prime}$ & $244^{\circ} 00^{\prime}-248^{\circ} 00^{\prime}$ & $241^{\circ} 00^{\prime}$ & $244^{\circ} 28^{\prime}$ & $1^{\circ} 32^{\prime}$ \\
\hline 17 & $\begin{array}{c}\text { ALHUDAA } \\
\text { (للهدى) }\end{array}$ & $\begin{array}{l}\text { ALRASIFA } \\
\text { (الرصيفة) }\end{array}$ & $047^{\circ} 00^{\prime}$ & $45^{\circ} 00^{\prime}-49^{\circ} 00^{\prime}$ & $043^{\circ} 00^{\prime}$ & $046^{\circ} 28^{\prime}$ & $0^{\circ} 32^{\prime}$ \\
\hline 18 & $\begin{array}{c}\text { ALMUHAISNI } \\
\text { (المحيسنين) }\end{array}$ & $\begin{array}{c}\text { ALEAZIZI } \\
\text { (العزيزية) }\end{array}$ & $276^{\circ} 30^{\prime}$ & $272^{\circ} 30^{\prime}-279^{\circ} 00^{\prime}$ & $275^{\circ} 00^{\prime}$ & $278^{\circ} 28^{\prime}$ & $-1^{\circ} 58^{\prime}$ \\
\hline
\end{tabular}




\begin{tabular}{|c|c|c|c|c|c|c|c|}
\hline 19 & $\begin{array}{c}\text { SULAIMAN } \\
\text { ALOBAID } \\
\text { (سليمان العبيا) } \\
\end{array}$ & $\begin{array}{c}\text { ALEAZIZI } \\
\text { (العزيزية) }\end{array}$ & $282^{\circ} 00^{\prime}$ & $278^{\circ} 00^{\prime}-284^{\circ} 30^{\prime}$ & $278^{\circ} 00^{\prime}$ & $281^{\circ} 28^{\prime}$ & $0^{\circ} 32^{\prime}$ \\
\hline 20 & $\begin{array}{l}\text { MUHAMAD } \\
\text { ALSABIL } \\
\text { (محمد المبيل) }\end{array}$ & $\begin{array}{l}\text { KUDI } \\
\text { (كدي) }\end{array}$ & $016^{\circ} 30^{\prime}$ & $13^{\circ} 00^{\prime}-18^{\circ} 30^{\prime}$ & $\mathbf{0 1 3}^{\circ} \mathbf{0 0}$ & $016^{\circ} 28^{\prime}$ & $0^{\circ} 02^{\prime}$ \\
\hline 21 & $\begin{array}{l}\text { MASJID } 35 \\
\text { (مسجد (م5 }\end{array}$ & $\begin{array}{c}\text { ALSITIYN St. } \\
\text { (ش الستين) }\end{array}$ & $098^{\circ} 00^{\prime}$ & $95^{\circ} 00^{\prime}-101^{\circ} 00^{\prime}$ & $096^{\circ} 00^{\prime}$ & $099^{\circ} 28^{\prime}$ & $-1^{\circ} 28^{\prime}$ \\
\hline
\end{tabular}

\section{REFERENCES}

1. ChulliatA,MacmillanS,AlkenP,BegganC,NairM,HamiltonB, WoodsA,RidleyV,MausS,ThomsonA （2015),."TheUS/UKWorld MagneticModelfor2015-2020:TechnicalReport",National GeophysicalDataCenter,NOAA,2015.

2. David A. King (1985). "ThE SACRED DiRECTION IN ISLAM A STUdY OF THE INTERACTION OF RELIGION AND SCIENCE IN THE MIDDLE AGES" , INTERDISCIPLINARY SCIENCE REVIEWS, VOL. 10, NO.4, 1985315.

3. David A. King (1995)."THE ORIENTATION OF MEDIEVAL ISLAMIC RELIGIOUS ARCHTURE AND CITIES", science history publication LTD., Provided by the NASA Astrophysics , 0021-828619512603-0253/\$2.5@1995.

4. David A. King (2018). "THE PETRA FALlACY - EARLY MOSQUES DO FACE THE SACRED KAABA IN MECCA BUT DAN GIBSON DOESN'T KNOW HOW" , www.davidaking.academia.edu CDavid A. King, 2018.

5. https://www.altafsir.com/

6. https://www.ngdc.noaa.gov/geomag/declination.shtml.

7. Ilyas M. Qibla and Islamic Prayer Times. In: Encyclopaedia of the History of Science, Technology, and Medicine in Non-Western Cultures. In: Geodesy. Netherlands, Springer, 2008.

8. OLIVIER ESSLINGER (2017)," INTRODUTION AL ASTRONOMIE",

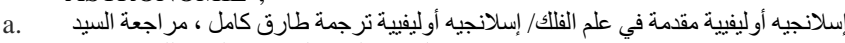

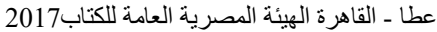

9. TonoSaksono, MohamadAliFulazzaky, and ZamahSari (2018)," Geodetic analysis of disputed accurate Qibla direction" , J.Appl.Geodesy2018;aop,uthenticated ｜ fulazzaky@gmail.com author's copy. Download Date | 2/4/18 11:36 PM.

10. Veli İLÇ̇, İbrahim Murat OZULU, Ersoy ARSLAN, Reha Metin ALKAN (2018),." Investigation on the Accuracy of Existing Qibla Directions of the Mosques from Different Periods: A Case Study in Çorum City, Turkey", https://doi.org/10.17559/TV-20170226111205 Original scientific paper- ISSN 1330-3651 (Print), ISSN 1848-6339 (Online).

\section{AUTHOR PROFILE}

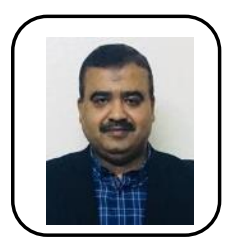

\section{A. M. Abdel-Wahab}

Assistant Professor Civil Engineering Department, National Research Centre, Egypt (NRC). Assistant Professor (Researcher) Civil Engineering Department, Engineering Research Division, National Research Center 2006 - Present. Geodesy and Remote sensing and Photogrammetry Consultant,- GIS Jeddah Municipality from May 2007 - January 2010. GIS Jeddah Municipality from May 2009 - January 2010. Geodesy and Remote sensing and Photogrammetry Consultant,- GIS Jeddah Municipality from May 2007 - January 2010. General Manager of GIS Jeddah Municipality from 2010 - 2014. Consultant for Vice Mayor Jeddah Municipality of construction 2014-2018. Member of Civil Engineering Unit of Engineering Research Division, National Research Center 2004 - present . Member of Ain Shams University Faculty of Engineering Surveying unit 1994- 2007. 